\title{
TECHNOLOGICAL TOOLS AND PROBLEM-BASED LEARNING TO PROMOTE CREATIVITY AND DESIGN IN ENGINEERING COURSES
}

\section{LEONARDO EMIRO CONTRERAS ${ }^{1}$, JOSÉ IGNACIO RODRÍGUEZ ${ }^{2} \&$ HECTOR}

\section{JAVIER FUENTES LOPEZ $Z^{3}$}

\author{
${ }^{I}$ Mechanical engineering. Faculty of Engineering. Universidad Distrital Francisco José de Caldas. Bogotá, Colombia. \\ ${ }^{2}$ Industrial engineering. Faculty of Engineering. Universidad Distrital Francisco José de Caldas. Bogotá, Colombia \\ ${ }^{3}$ Economist. Faculty of Engineering. Universidad Distrital Francisco José de Caldas.Bogotá, Colombia.
}

ABSTRACT
This document discusses how the problem-based learning methodology has been used in an engineering course in
order to not only improve academic performance in students but also generate new creative and professional skill
sets. A brief theoretical framework is developed as well as a pilot of traditional learning methods and their application
between 2017 and 2019. Finally, the obtained results are presented for each academic period and they are discussed
in terms of statistics and design.
KEYWORDS: Problem-based Learning, Creativity, Engineering Design, Engineering Education, ICTs

Received: Oct 08, 2020; Accepted: Oct 28, 2020; Published: Nov 12, 2020; Paper Id.: IJMPERDOCT202044

\section{INTRODUCTION}

The world is currently experiencing different changes in the knowledge field including the education sector. In this sense, universities and particularly engineering programs, are demanding academic changes in order to reach quality standards and qualifications that can shape highly capable professionals in terms of academic, scientific and technological mindsets with creative and innovative abilities (Gazabon \& Ovallos, 2015).

The use of new technologies (ICTs) with pedagogic goals can help teachers find new teaching methods (Esquembre, 2004), that can banish memory-based knowledge and motivate students to generate knowledge by trying to solve everyday problems (Tristancho et al., 2017).

The foundation of many engineering courses are physics and mathematics. Usually, students learn formulas that are used in terms of the data describing the problem, in order to solve it mechanically and nonreflexively. In many cases, a "good student" that can solve problems without profound analysis is often mixed up by one that can truly face real problems (Rodriguez et al., 1999).This work has been focusing on proposing and assessing learning engineering methodologies especially in the applied mechanics course using techniques and technologies. Practice has proven that students lack computer resources to really grasp phenomena and generate new creativity skills that boost his competitiveness (Ausín et al., 2016).

\section{MATERIALS AND METHODS}

Society demands students not only capable of acquiring new knowledge but also creating products that can solve 
problems within their community (Litzinger et al., 2011). Hence, it is important to educate engineering students not just from a memory-based skillset. In fact, computing tools need to be integrated into the classroom pedagogy, helping teachers find new ways to learn, teach and help students create developments that serve society in specific issues. Although the issues tackled are not always complex, the solutions are based on engineering tools and knowledge (De Miguel, 2005)

As a consequence, this work focuses on the need to involve the student in his own learning process, so that he can participate, experiment and offer solutions to a problem and analyze results, make decisions, redefine the procedure if necessary and eventually conclude with depth regarding the problem or its solution (Contreras \& Tarazona, 2018).

\section{1 teaching in Engineering}

Traditional teaching in engineering and, especially in applied mechanics, is characterized by a teacher that delivers a series of concepts using methodologies centered on his everyday activity (presentations, solving theoretical problems, etc.). The tasks are iterative and memory-based (solving equations and calculations) that frequently reward the person that remembers the instructions even if the studied phenomenon is not completely understood (Bohórquez Gómez-Millán \& Checa Esquiva, 2019). The role of the student is completely passive and allows little development of everyday phenomena, creativity, innovation skills that are useful in professional settings (Vargas \& Contreras, 2007).

The conceptual conclusions on the phenomenon are left aside meaning that the solution is not connected to the real life engineering practice as expressed by (Gil \& De Guzman, 1993). This appreciation is also shared by (Ausín et al., 2015) who states that the dependence on text books and instructions for masses is obsolete in the era of information and research should focus on assessing and improving learning methodologies by appropriating new techniques and existing technologies.

\subsection{Didactic Transformation of Engineering}

Different methodologies can facilitate learning such as active learning where the student participates, manipulates, experiences and proposes solutions to a problem (Tristancho Ortiz et al., 2015). Another methodology is problem-based learning centered in learning and thinking to solve real problems posed by the teacher (Bohórquez Gómez-Millán \& Checa Esquiva, 2019).

This method favors the possibility to interrelate different subjects or disciplines in which students work in small groups (Luy-Montejo, 2019) to solve a problem by using previously acquired knowledge. This helps students study the environment, reflect, communicate ideas and integrate the previous knowledge (Fernández \& Duarte, 2013).

\subsection{Creativity}

(Camacho \& Fuentes, 2013) define creativity as the aptitude, capacity and skills for problem solving. (Galeano, 2002) states that creativity brings renewed ways to analyze the intrinsic nature of a problem, offering a variety of possible solutions. According to (Ramos, 2006), it is the result of the original and the new and (Hernadez \& Alavarado; Juan, 2015) describes it as the thorough use of intelligence.

Teaching in engineering is known to be flexible in terms of methodological strategies that drive skills in future engineers through technological tools (Merchán et al., 2011). 


\subsection{CAD Software Guided Teaching}

Computer Assisted Design (CAD) has been introduced in education and the industry allowing to visualize and manipulate objects in 2D and 3D thus facilitating the development of special skills in students (López \& Vázquez, 2001). Tools such as Solid Edge ${ }^{\circ}$ o SolidWorks $\left.{ }^{\circledR}\right)$ include finite element methods (FEM) that foster the development and design of different products for various branches of engineering. Design can be analyzed from distinct usage conditions, leaving the process of numerical calculations to the tool and not to the human. This is achieved by adding loads, restraints and properties to the materials.

These programs often have a library assorted with multiple kinds of materials that can be tested for the developed CAD project. Physical and mechanical properties can be modified as well as resistance, density, effort limits and deformation constants (Vargas Tamayo, 2007).

\section{METHODOLOGY}

The methodology adopted in the study consists on the following steps: (1) Strategy, (2) Participants, (3) Environmentrelated problems and (4) Results.

\subsection{Strategy}

The teacher presents a real problem that must be tackled by groups of students to propose a solution. It must integrate knowledge of previous courses in the areas of design and manufacturing. The design should be creative and follow the

cycle presented in

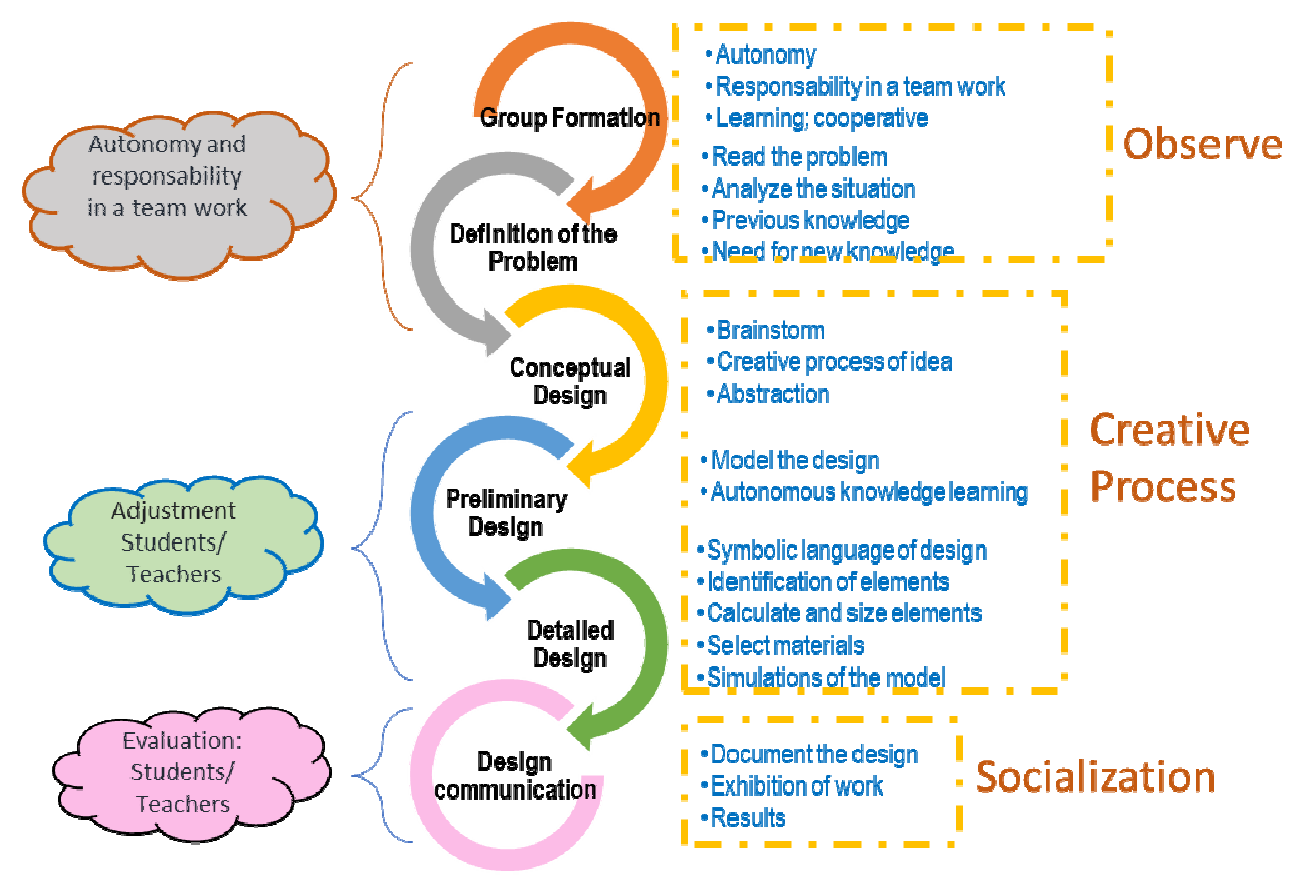

Figure 1. 


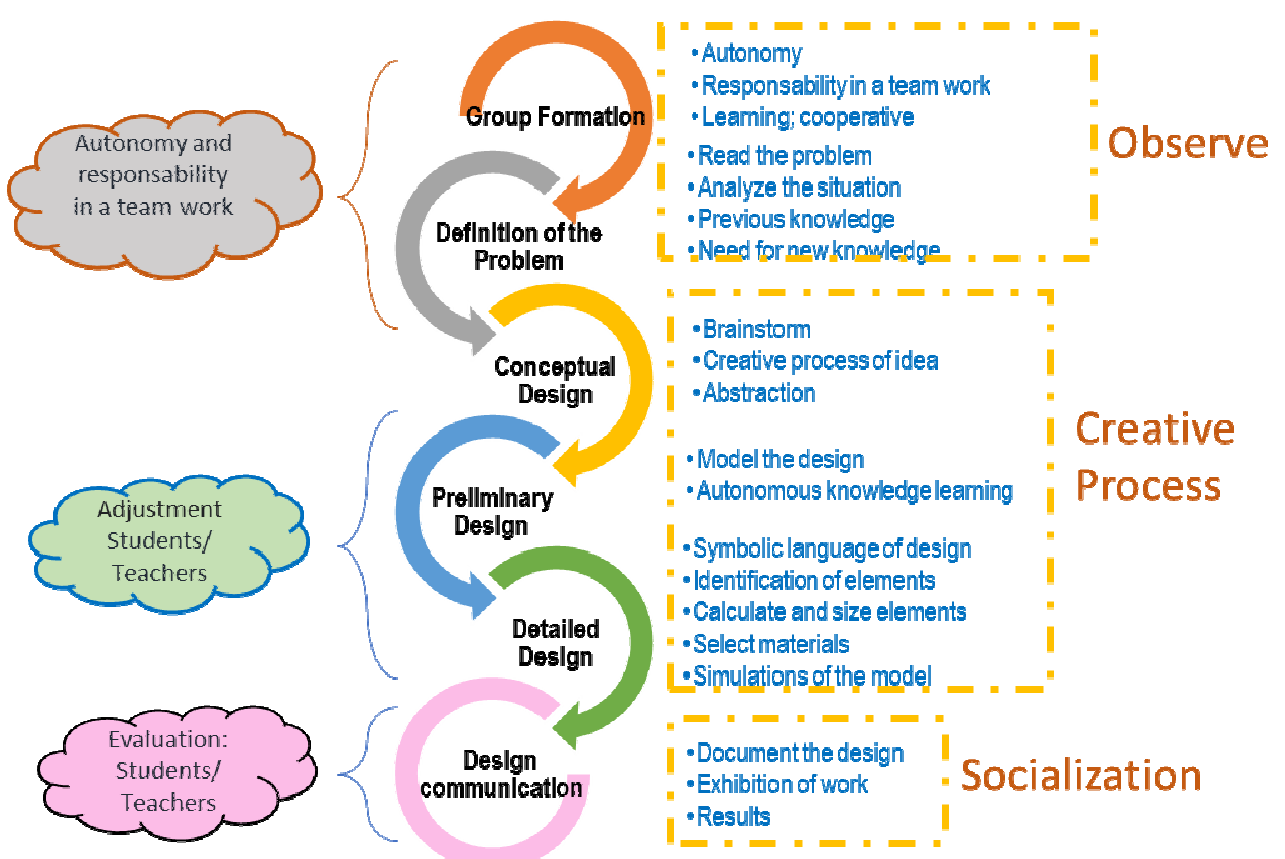

Figure 1: Strategy implemented in the applied mechanics course. Source: Authors.

\subsection{Participants}

This project has included students of the applied mechanics course in the Industrial Engineering project of Universidad Distrital (Colombia) during the 2017 - 2019 period.

\subsection{Environment-Related Problems}

Through the use of the problem-based methodology, various problems were proposed that needed to be solved by students that were enrolled in the course between 2017 and 2019 in order to acquire the same knowledge of a regular class (fictitious problems). These are shown in Table 1

Table 1: Reviewed topics per semester(Authors)

\begin{tabular}{|c|c|c|c|}
\hline $\mathbf{2 0 1 7}$ & I & Solving the problem of excessive plastic waste from pens after being used by people \\
\hline $\mathbf{2 0 1 7}$ & II & Redesign devices that allow mobility for handicapped people in their lower limbs \\
\hline $\mathbf{2 0 1 8}$ & I & $\begin{array}{c}\text { Propose the design of the furniture in computing labs of the university, so that the } \\
\text { available space is better distributed whilst meeting the anthropometric and lighting } \\
\text { standards }\end{array}$ \\
\hline $\mathbf{2 0 1 8}$ & II & $\begin{array}{c}\text { Solving mobility issues for people in Bogotá (Colombia) through an environment- } \\
\text { friendly device that can transport at least three people }\end{array}$ \\
\hline $\mathbf{2 0 1 9}$ & I & II & $\begin{array}{c}\text { Solve the recycler problem in Bogotá in terms of the transportation method used } \\
\text { Given to the generation of garbage in the residential urban area of Bogotá } \\
\text { (recycling spots) }\end{array}$ \\
\hline
\end{tabular}




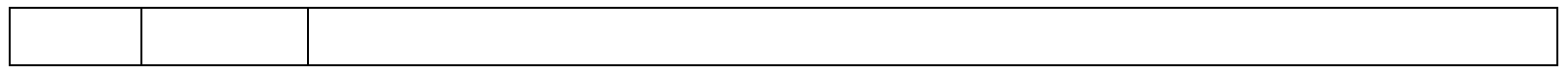

\section{RESULTS}

In the 2017-1 period, groups of students that enrolled in the course proposed conceptual designs for a device to write. The resulting redesigns of the conventional pen (Figure 2) were ergonomic and used environment-friendly materials and waterbased ink. The quality function deployment method was adopted.
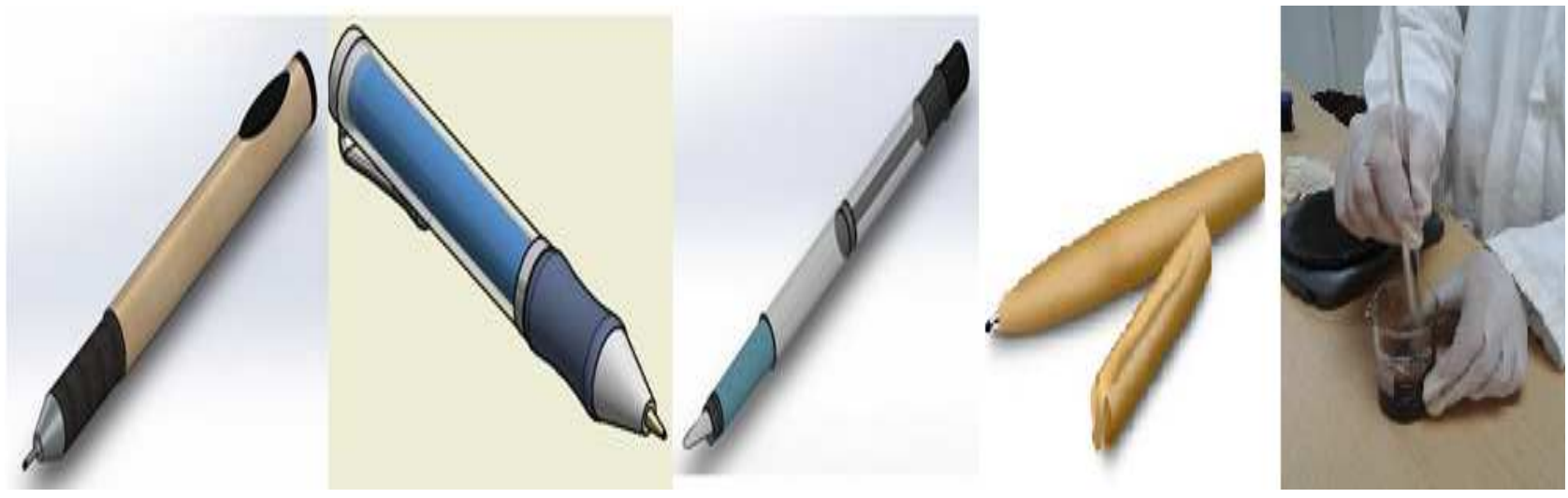

Figure 2: Solution to waste production from pens that affects the environment.

Source: Applied mechanics students 2017-I

In the 2017-II academic period, the students proposed conceptual designs of a device that can facilitate the mobility of handicapped people during their growing stages (between 8 and 15 years old). These designs were built with a CAD software and FEA of the key parts subjected to different types of loads and effort situations. Furthermore, polls were made to perform a QFD (Figure 3).
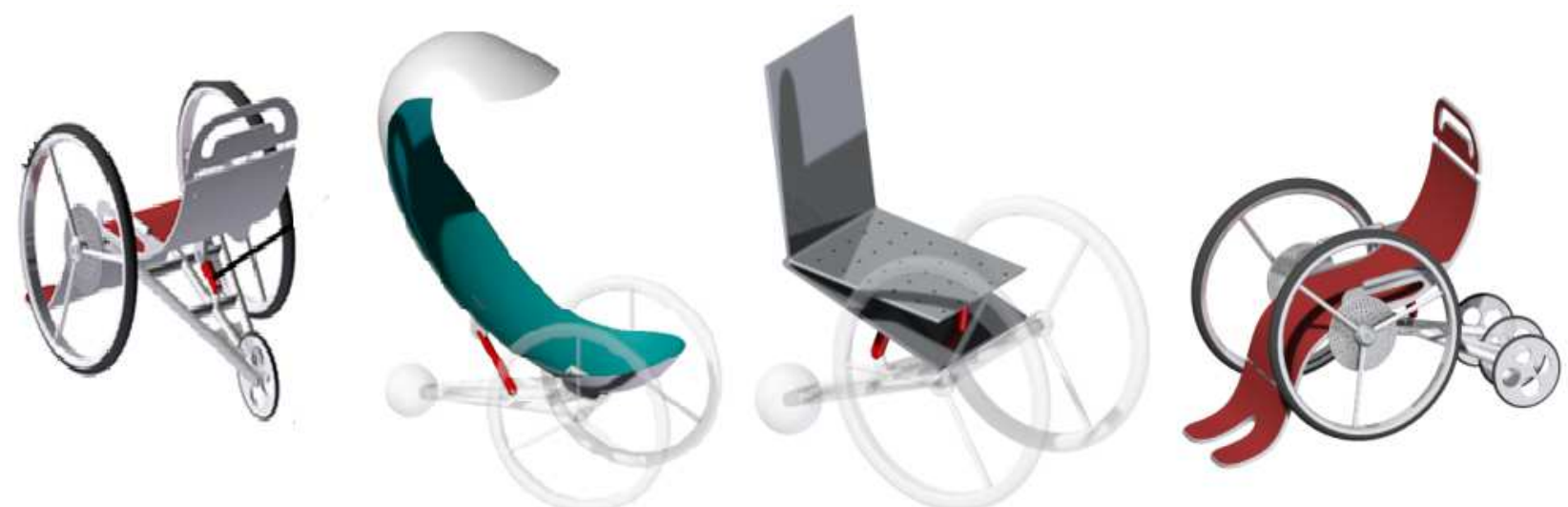

Figure 3: Redesigns for the handicapped problem.Source: Applied mechanics students 2017-II

In the 2018-I period, students studied the anthropometric features of current users of technological tools and their need to move and interact with them. Hence, conceptual designs were proposed that considered the application of occupational hygiene, ergonomics, design and science of materials (Figure 4). 

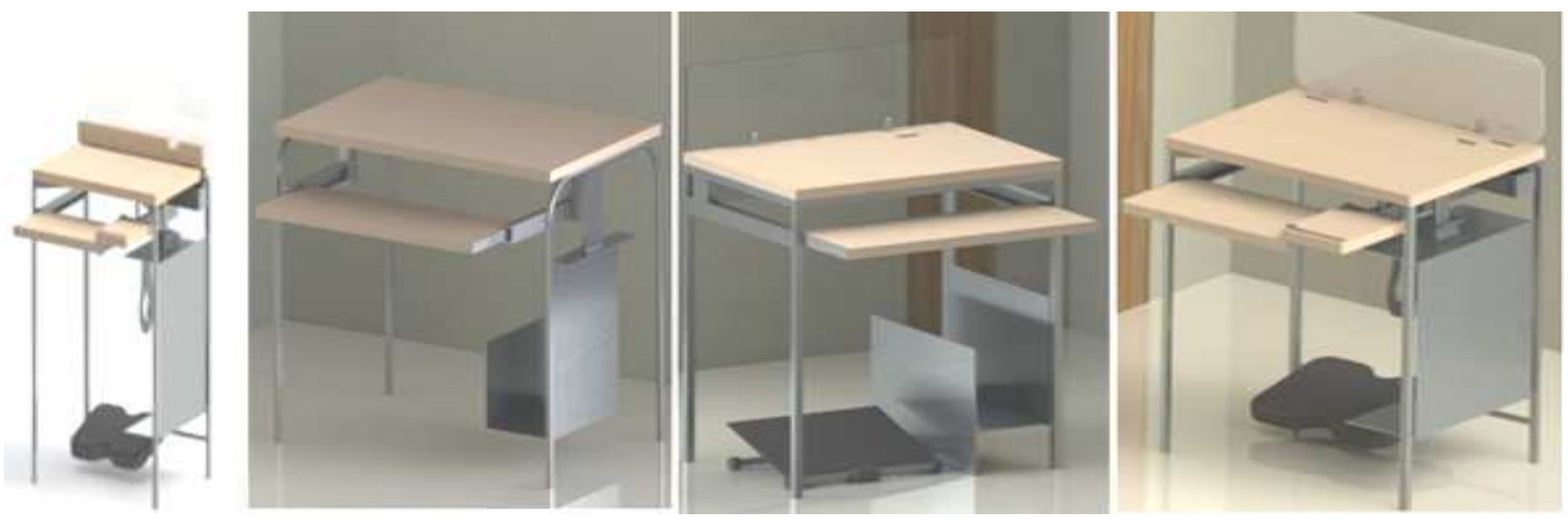

Figure 4: Possible solutions to the computing room furniture problem.

\section{Source: Students from Applied Mechanics 2018-I}

In 2018-II, the subject problem consisted on proposing possible solutions to the mobility problem in Bogotá (Colombia) through a device that can carry at least three people. Students proposed prototypes that considered the existing normativity (traffic, transportation, environment and ergonomics) as well as the efforts and deformations to which the product elements will be subjected to under different loads and reactions (Figure 5). Motion simulations were also performed.
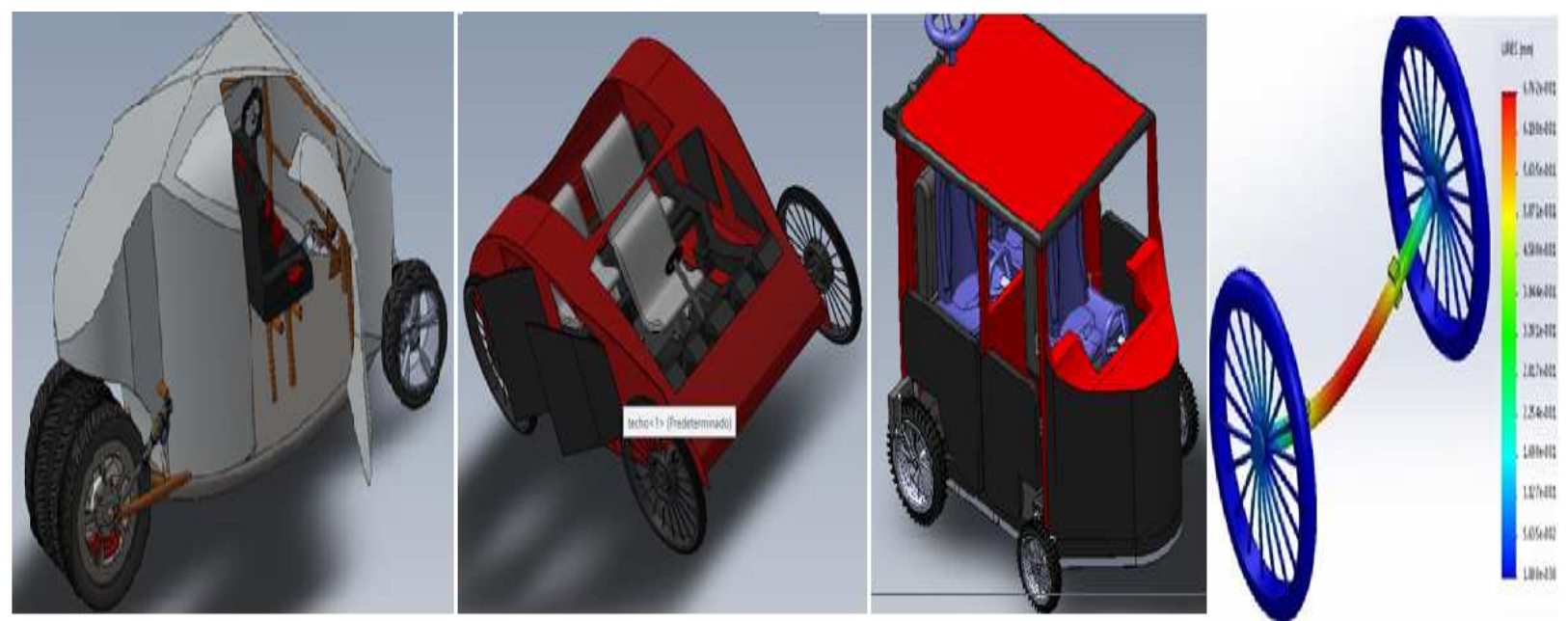

Figure 5: CAD and FEA designs. Source: Applied mechanics students 2018-II

In the 2019-I period, the focus consisted on giving solution to the recycling and garbage recollection system from the viewpoint of the recycler. Figure 9 shows one of their common transportation methods in Bogotá which do not ease mobility, are not comfortable for the user and do not have enough space to carry waste. In order to contribute to the solution of this paradigm, students proposed designs for the transportation and classification of recycled materials (cardboard, plastic, paper and glass) which are pulverized as the bicycle pedal is moved. Additionally, storage capacity was increased to the sides of the vehicle. 

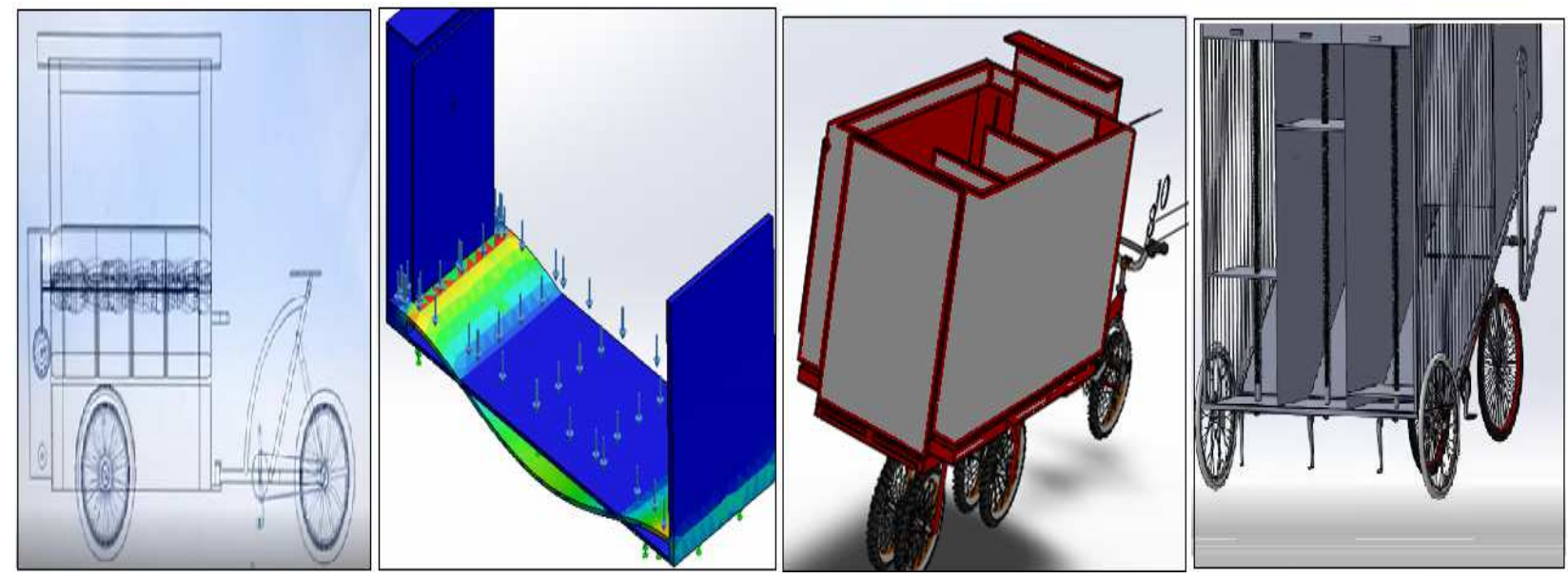

Figure 6: Prototypes for recyclable material recollection. Source: Students of applied mechanics 2019-I

In 2019-II, the problem at hand was to solve garbage generation in the residential area of Bogotá using the problem-based learning method. In figure 7, a finite element analysis is shown regarding one of the constitutive elements of the designs for specific loads, efforts and paths since design calculations required computing tools.
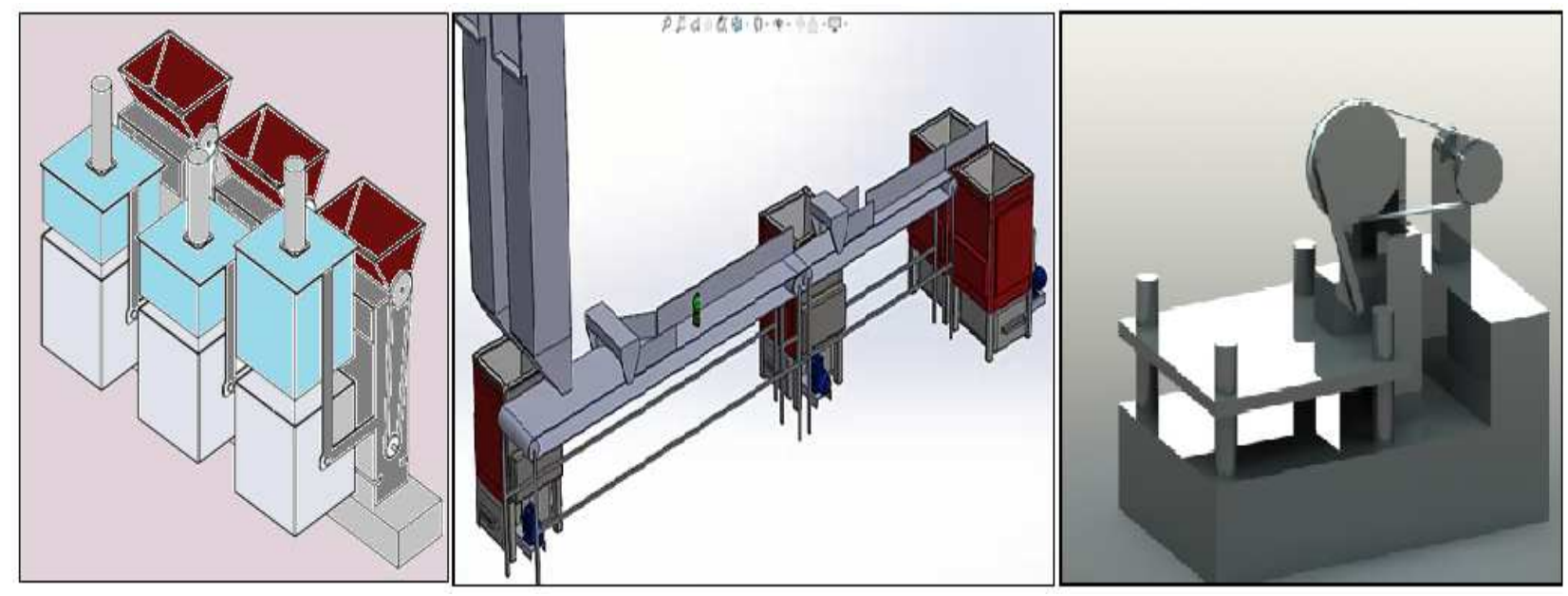

Figure 7: CAD and FEA designs of recycling systems proposed for residential areas.

Source: Students of applied mechanics 2019-II

The results correspond to the academic results at the end of each course and the polls made between 2017 and 2019 with multiple option and open answer (Figure 8). 


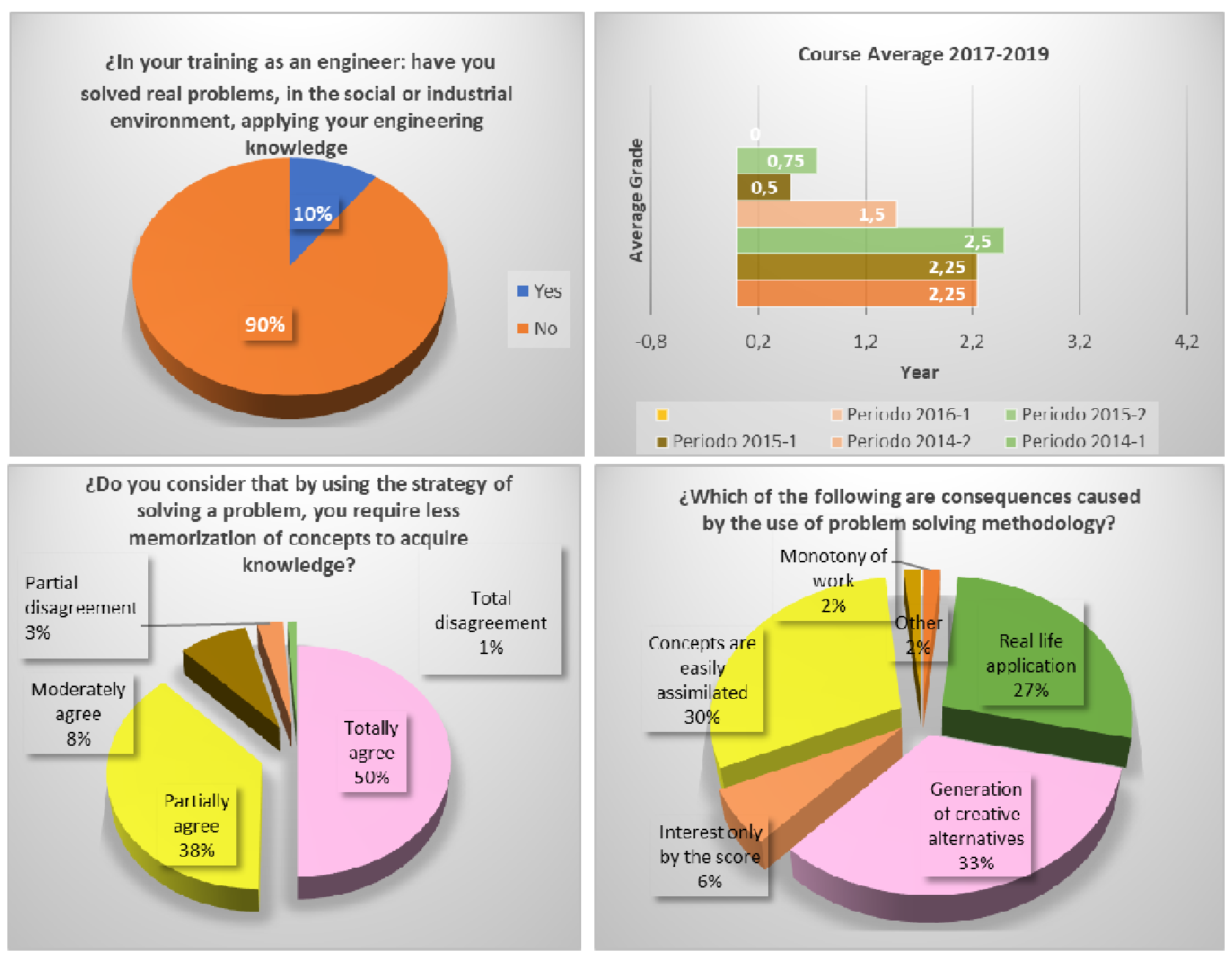

Figure 8: Some statistical results of CAD and BPL application in engineering. Source: Authors.

The results reflect that most students had an improvement in their academic performance using technological and problem-based learning. They stated that the methodology is suitable since it can drive the knowledge acquired during their education to apply it in the development of the project. In fact, they developed design-related skills that they had not used in other courses of design and manufacturing, going from a memory-based framework to an application.

\section{DISCUSSIONS}

An important contribution of this work is that it helps overcome the deficiencies of traditional learning such as monotony, lack of interest, allowing students to apply knowledge and improving their technological skills, assuming responsibilities and promoting abilities that were not encompassed with traditional methodologies. This shows that it is necessary to bolster the teaching process with a higher degree of student satisfaction.

The work developed in the classroom by students confirm that the methodological change aiming towards new problem-solving methods is beneficial in the professional scenario through a more flexible methodology that promotes creativity and innovation as stated by (Reyes, 2004). The author confirms the need to use creative strategies combined with traditional ones to reach higher motivation in students so that their learning process is improved and new knowledge can be generated. This translates into business entrepreneurships, prototype development and practical solutions that enhance the quality of life of people. 
The change of methodology was initially a harsh deviation for both students and teachers. It allowed students to generate new designs that revealed the importance of learning aspects that had not been discovered in previous classes. This was no excuse to keep searching for information, concepts and techniques to promote good results in their designs.

\section{CONCLUSIONS}

Combining technological tools with a convenient methodology allows the use of engineering techniques and skills that can help manage projects and shape mindsets for the current professional environment.

The problem-based learning approach enabled students to integrate knowledge from science of materials and mechanical processes with applied mechanics that led to new creative solutions to real problems.

This could be considered as the first step in the detection of weaknesses within the educational process of industrial engineers which can be extrapolated to other areas of knowledge since teachers tend to recreate the methodologies that they received throughout their own education. The goal is to drift away from a collective training towards the generation of basic, specific and skills required by engineers today.

\section{REFERENCES}

1. Ausín, V., Abella, V., Delgado, V., \& Hortigüela, D. (2015). Aprendizaje Basado en Proyectos a través de las TIC. Una Experiencia de Innovación Docente Aprendizaje Basado en Proyectos a través de las TIC. Una Experiencia de Innovación Docente desde las Aulas Universitarias. 9(10).

2. Ausín, V., Abella, V., Delgado, V., \& Hortigüela, D. (2016). Aprendizaje Basado en Proyectos a través de las TIC. Una Experiencia de Innovación Docente desde las Aulas Universitarias.Revista Formación Universitaria, 9(3), 31-38.

3. Bohórquez Gómez-Millán, M. R., \& Checa Esquiva, I. (2019). Desarrollo de competencias mediante ABP y evaluación con rúbricas en el trabajo en grupo en Educación Superior. REDU: Revista de Docencia Universitaria, 10(2), 121-147.

4. Camacho, I., \& Fuentes, J. (2013). Desarrollo de la creatividad de los docentes en formación mediante el uso de metáforas en entornos virtuales de aprendizajes. Edutec, $1,14$.

5. Contreras, L., \& Tarazona, G. (2018). Big Data: An Exploration Toward the Improve of the Academic Performance in Higher Education. Lecture Notes in Computer Science, 10943, 627-637.

6. De Miguel, M. (2005). Modalidades de enseñanza centradas en el desarrollo de competencias. Orientaciones para promover el cambio metodológico en el Espacio Europeo de Educación Superior. España: Ediciones de la Universidad de Oviedo (primera).

7. Esquembre, F. (2004). Fislets : enseñanza de la física con material interactivo. Pearson Educación.

8. Fernández, F. H., \& Duarte, J. E. (2013). El aprendizaje basado en problemas como estrategia para el desarrollo de competencias específicas en estudiantes de ingeniería. Formacion Universitaria, 6(5), 29-38.

9. Galeano, A. (2002). Viaje Al Fondo De La Creatividad (Editorial Politécnico Grancolombiano (ed.); First Edition). https://articulo.mercadolibre.com.co/MCO-460946725-viaje-al-fondo-de-la-creatividad-_JM

10. Gazabon, D., \& Ovallos, P. (2015). Creativity, innovation and entrepreneurship in the training of engineers in Colombia. A pro-spective study. Rev. Educación En Ingeniería, 10(19), 90-104.

11. Gil, D., \& De Guzman, M. (1993). Enseñanza de las Ciencias y la Matemática Tendencias e Innovaciones (Organización de Estados Iberoamericanos (ed.); Primera, Vol. 1). Popular. 
12. Hernadez, I., \& Alavarado; Juan. (2015). Revista Virtual Universidad Católica del Norte (Issue 44). Católica del Norte Fundación Universitaria.

13. Litzinger, T. A., Lattuca, L. R., Hadgraft, R. G., \& Newstetter, W. C. (2011). Engineering Education and the Development of Expertise. Journal of Engineering Education, 100(1), 123-150.

14. López, E., \& Vázquez, M. (2001). El método de los Elementos Finitos, aplicado al análisis estructural (Primera, Vol. 1). Editorial Nohelia. z

15. Luy-Montejo, C. (2019). Problem Based Learning (PBL) in the Development of Emotional Intelligence of University Students. Propósitos y Representaciones, 7, 353-383.

16. Merchán, E. A., Lugo, E., \& Hernández, L. (2011). Aprendizaje significativo apoyado en la creatividad e innovación. Revista de La Asociación Mexicana de Metodología de La Ciencia y de La Investigación, 3(1).

17. Ramos, M. (2006). Educadores creativos, alumnos creadores:Teoría y práctica (2006 San Pablo (ed.); 1st ed.). San Pablo, 2006.

18. Reyes, M. (2004). Las estrategias creativas como factor de cambio en la actitud del docente para la enseñanza de la matemática. Revista Universitaria de Investigación, 4(2), 1-26.

19. Rodriguez, G., Gil, J., \& Garcia, E. (1999). Metodología de la Investigación Cualitativa. (Primera ed, Vol. 1). Ediciones Aljibe.

20. Tristancho, J., \&Fuentes, H. (2017). Uso de las herramientas informáticas educacionales para la enseñanza de la resistencia de materiales. Revista Virtual Universidad Católica Del Norte, 50(2), 299-321.

21. Tristancho Ortiz, J. A., \& Vargas Tamayo, L. (2015). Análisis y aplicación de técnicas de aprendizaje activo en mecánica aplicada. Revista Educación y Desarrollo Social, 8(2), 28-45.

22. Vargas, F., \& Contreras, L. (2007). Enseñanza de la mecánica de materiales enriquecida con herramientas computacionales. Revista Ingenieria, v.12(2), 66-73.

23. Vargas Tamayo, L. F. (2007). Enseñanza de la mecánica de materiales enriquecida con herramientas computacionales. Ingeniería, 12(1), 64-71. 